\title{
Desain Topologi Jaringan Kabel Nirkabel PDII- LIPI dengan Cisco Three-Layered Hierarchical menggunakan NDLC
}

\author{
M. TEGUH KURNIAWAN ${ }^{1}$, ARIF NURFAJAR ${ }^{2}$, OKTA DWI ${ }^{3}$, UMAR YUNAN ${ }^{4}$ \\ 1,2,3,4Program Studi Sistem Informasi Fakultas Rekayasa Industri Telkom University \\ mtk@telkomuniversity.ac.id
}

\begin{abstract}
ABSTRAK
Saat ini Teknologi Informasi (TI) merupakan salah satu hal yang penting dalam suatu perusahaan. Dalam penerapan TI diperlukan infrastruktur jaringan yang dapat mendukung pertukaran informasi baik melalui intranet mauapun internet yang diakses melalui kabel maupun nirkabel. Salah satu pendukung Infrastruktur jaringan adalah topologi jaringan yang handal. PDII-LIPI (Pusat Dokumentasi dan Informasi IImiah - Lembaga Ilmu Pengetahuan Indonesia) Jakarta merupakan lembaga di bawah LIPI yang berfokus pada tiga kegiatan yaitu jasa dokumentasi, jasa informasi, pembinaan dan pengembangan bidang dokumentasi informasi. Untuk mendukung proses bisnis berbasis TI di PDII-LIPI diperlukan infrastruktur jaringan yang memadai. Oleh karena itu, pada penelitian ini dilakukan perancangan infrastruktur jaringan kabel dan nirkabel di PDII-LIPI dengan menggunakan metode Network Development Life Cycle (NDLC). Metode ini berguna dalam mengembangkan infrastruktur jaringan kabel dan nirkabel dan dapat memantau kinerja jaringan. Dengan penelitian ini diharapkan dapat membantu PDII-LIPI dalam membangun, dan mengembangkan infrastruktur jaringan kabel dan nirkabel agar lebih optimal dalam mendukung proses bisnis yang ada.
\end{abstract}

Kata Kunci : topologi jaringan, kabel, nirkabel, NDLC, PDII-LIPI.

\section{ABSTRACT}

Information Technology (IT) has significant influence to a company. The robust network IT infrastructure should be installed earlier, supporting the information exchange through internet or intranet and it also should be easily accessible via wired or wireless network. PDII-LIPI (Pusat Dokumentasi dan Informasi IImiah - Lembaga IImu Pengetahuan Indonesia) Jakarta is an organization under LIPI which focuses on three processes for instance the documentation services, the information services and the development of documentation services. PDII-LIPI has already used IT to support those businesses so they must carefully choose the best network IT infrastructure. To achieve this objective, we propose a research which design wired and wireless network infrastructure at PDII - LIPI. We use Network Development Life Cycle (NDLC) as a method for solving problem. This method is very useful in developing wired and wireless network infrastructure and it can monitor network performance. We expect the research can help PDII - LIPI in building and developing the infrastructure of wired and wireless networks to be more optimized in supporting existing business processes.

Keywords : network topology, wired, wireless, NDLC, PDII-LIPI. 


\section{PENDAhuluan}

Penggunaan internet baik yang diakses melalui media kabel maupun nirkabel merupakan salah satu penerapan Teknologi Infomasi (TI) yang sudah digunakan di seluruh dunia tak terkecuali di PDII-LIPI. Pengguna internet di Indonesia sudah mencapai 82 juta orang (Kominfo, 2014), data ini didukung oleh statistik pengguna internet di Indonesia yang dikeluarkan oleh Asosiasi Penyedia Jasa Internet Indonesia (APJII) untuk beberapa tahun kemudian (APJII, 2014). Dengan semakin meningkatnya akan kebutuhan komunikasi data dan pertukaran informasi baik skala intranet maupun internet maka diperlukan dukungan infrastruktur jaringan untuk jalannya komunikasi data atau pertukaran informasi. Dan infrastruktur sendiri memerlukan dukungan topologi jaringan yang handal. Klasifikasi jaringan komputer berdasarkan media transmisinya terbagi menjadi dua yaitu (Tanenbaum, 2011) :

a. Jaringan Kabel, dimana dalam mengakses jaringan komputer menggunakan media kabel baik kabel copper maupun kabel fiber optik.

b. Jaringan Nirkabel, dimana dalam mengakses jaringan komputernya tanpa menggunakan media kabel atau wireless. Dimana penggunaannya menggunakan media gelombang radio.

Pusat Dokumentasi Dan Informasi Ilmiah - Lembaga Ilmu Pengetahuan Indonesia (PDIILIPI) merupakan lembaga yang berfokus pada tiga jenis kegiatan utama yaitu jasa dokumentasi, jasa informasi, pembinaan dan pengembangan di bidang dokumentasi informasi (PDII-LIPI, 2011).

Pada PDII-LIPI sudah terdapat topologi jaringan yang digunakan untuk mendukung beberapa kegiatan di PDII-LIPI baik jaringan kabel LAN jenis UTP maupun nirkabel. Saat ini, topologi eksisting Infrastruktur jaringan pada PDII-LIPI memiliki fungsi untuk mendukung beberapa kegiatan seperti pada kegiatan penyimpanan informasi ilmiah dan penyediaan jurnal. Terdapat beberapa keluhan yang dikeluhkan pegawai. Untuk Jaringan Kabel LAN UTP, belum terdokumentasinya topologi jaringan LAN baik fisik maupun logik (IP Address) sehingga menyulitkan dalam hal monitoring dan perbaikan. Selain itu, topologi saat ini masih belum redundan sehingga ketika kabel utama putus menyebabkan semua koneksi putus. Untuk keluhan jaringan nirkabel, sulitnya pegawai PDII-LIPI untuk mengakses jaringan nirkabel dimana saat ini menggunakan wireless 802.11b dan 802.11g dengan kecepatan transfer 54 Mbps mengggunakan router WRT54GL. Kondisi yang terjadi saat ini adalah tidak meratanya penyebaran sinyal oleh Access Point (AP) sehingga proses akses jaringan hanya di tempat-tempat tertentu saja. Selain itu, tidak adanya monitoring dari pegawai PDII-LIPI secara berkala terhadap jaringan pada saat ini. Dan tidak adanya pendokumentasian topologi jaringan sehingga membuat sulit dalam troubleshooting dan maintenance.

Dalam merancang desain topologi jaringan usulan pada PDII-LIPI metode yang digunakan adalah Network Development Life Cycle (NDLC) dan konsep Cisco Three-Layer Hierarchial Design Model. Perbaikan topologi jaringan yang diusulkan diharapkan akan membantu proses bisnis PDII-LIPI dalam mendukung pertukaran data dan informasi baik dengan menggunakan intranet maupun internet.

Dari latar belakang diatas didapatkan rumusan masalah sebagai berikut:

1. Bagaimana identifikasi dan analisa topologi eksisting jaringan kabel dan nirkabel di PDII-LIPI

2. Bagaimana desain rancangan dan analisa topologi jaringan kabel dan nirkabel usulan di PDII-LIPI 
Dari rumusan masalah tersebut didapat tujuan sebagai berikut :

1. Mengidentifikasi dan analisa topologi eksisting infrastruktur jaringan kabel dan nirkabel di PDII-LIPI

2. Mendesain rancangan dan analisa topologi jaringan kabel dan nirkabel usulan di PDIILIPI

Jaringan komputer adalah suatu himpunan interkoneksi sejumlah komputer autonomous, atau dengan kata lain adalah kumpulan beberapa komputer (dan perangkat lain seperti printer, hub, switch, dan sebagainya) yang saling terhubung satu sama lain melalui media perantara (Sofana, 2008).

Berdasarkan media transmisinya jaringan komputer terbagi menjadi dua (Tanenbaum, 2011) yaitu :

1. Jaringan Kabel (wired)

Jaringan komputer yang menggunakan kabel sebagai media transmisinya. Kabel yang digunakan pada umumnya berbahan dasar tembaga seperti kabel twisted pair. Selain itu ada juga kabel jenis lain yaitu kabel coaxial dan kabel fiber optik (fo).

2. Jaringan Nirkabel (wireless)

Jaringan komputer yang menggunakan gelombang elektromagentika atau gelombang radio sebagai media transmisinya. Jaringan wireless memiliki tingkatan mulai dari Wireless Personal Area Network (WPAN), Wireless Local Area Network (WLAN), Wireless Metropolitan Area Network (WMAN), sampai Wireless Wide Area Network (WWAN).

Berikut adalah standar jaringan nirkabel menurut IEEE untuk Wireless Local Area Network atau untuk teknologi Wireless Fidelity (Wifi).

Tabel 1. Standar Wifi IEEE 802.11 (Cisco, 2014)

\begin{tabular}{|l|l|l|l|}
\hline Standard & Maximum Speed & Frequency & $\begin{array}{l}\text { Backwards } \\
\text { compatible }\end{array}$ \\
\hline $802.11 \mathrm{a}$ & $54 \mathrm{Mbps}$ & $5 \mathrm{GHz}$ & No \\
\hline $802.11 \mathrm{~b}$ & $11 \mathrm{Mbps}$ & $2.4 \mathrm{GHz}$ & No \\
\hline $802.11 \mathrm{~g}$ & $54 \mathrm{Mbps}$ & $2.4 \mathrm{GHz}$ & $802.11 \mathrm{~b}$ \\
\hline $802.11 \mathrm{n}$ & $600 \mathrm{Mbps}$ & $2.4 \mathrm{GHz}$ or $5 \mathrm{GHz}$ & $802.11 \mathrm{~b} / \mathrm{g}$ \\
\hline $802.11 \mathrm{ac}$ & $1.3 \mathrm{Gbps}(1300 \mathrm{Mbps})$ & $2.4 \mathrm{GHz}$ and $5.5 \mathrm{GHz}$ & $802.11 \mathrm{~b} / \mathrm{g} / \mathrm{n}$ \\
\hline $802.11 \mathrm{ad}$ & $7 \mathrm{Gbps}(7000 \mathrm{Mbps})$ & $2.4 \mathrm{GHz}, 5 \mathrm{GHz}$ and $60 \mathrm{GHz}$ & $802.11 \mathrm{~b} / \mathrm{g} / \mathrm{n} / \mathrm{ac}$ \\
\hline
\end{tabular}

\section{METODOLOGI PENELITIAN}

\section{Network Development Life Cycle (NDLC)}

Network Development Lifecyle (NDLC) merupakan suatu metode yang digunakan dalam mengembangakan atau merancang topologi jaringan yang memungkinkan terjadinya pemantauan jaringan untuk mengetahui statistik dan kinerja jaringan. Dari analisis kinerja tersebut dapat dijadikan sebagai pertimbangan perubahan desain jaringan, baik desain jaringan yang bersifat fisik atau jaringan logis seperti skema routing, pengelamatan jaringan, prioritas lalu lintas data, keamanan dan manajemen (James, 2004). Pada penelitian ini tahapan NDLC hanya sampai pada tahap simulasi prototipe. Dimana tahapannya sebagai berikut : 
a. Tahap Analisis, pada tahap ini dilakukan dengan menganalisa kondisi eksisting topologi jaringan komputer di PDII-LIPI mencakup topologi jaringan kabel dan nirkabel, perangkat yang digunakan, pemetaan access point, dan jangkauan access point.

b. Tahap Desain, pada tahan ini dilakukan proses perancangan desain topologi usulan untuk PDII-LIPI sesuai dengan analisa kondisi eksisting yang mencakup topologi jaringan kabel dan nirkabel, perangkat yang diusulkan, pemetaan access point.

c. Tahan Simulasi prototipe, pada tahan ini dilakukan pengukuran terhadap desain usulan yang merupakan pengujian jangkauan access point.

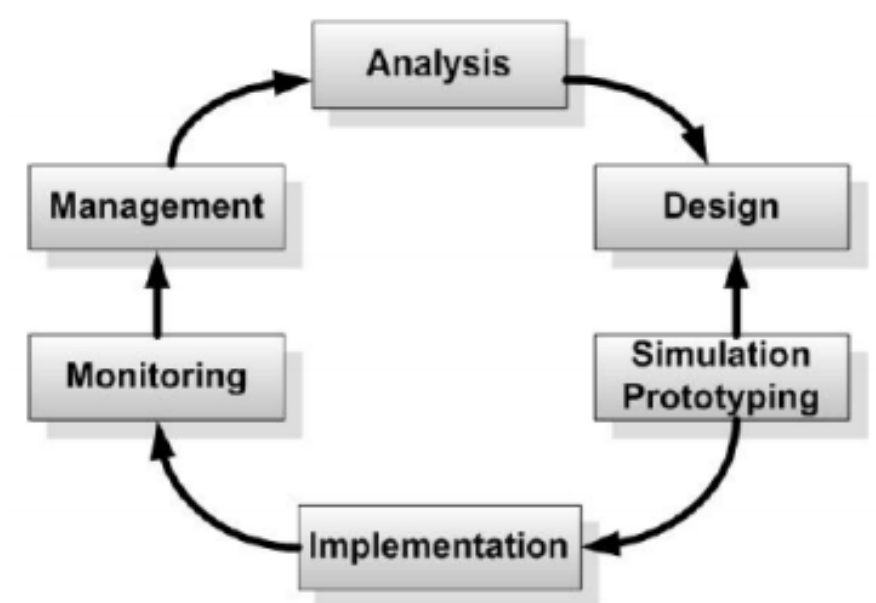

Gambar 1. Network Development Life Cycle (NDLC) (James, 2001)

Adapun tahapan NDLC sesuai dengan Gambar 1 adalah sebagai berikut (James, 2001) :

1. Analisis

Tahap awal ini dilakukan analisa kebutuhan, analisa permasalahan yang muncul, analisa keinginan pengguna, dan analisa topologi / jaringan yang sudah ada saat ini. Biasanya metode yang digunakan seperti wawancara, survei dll.

2. Desain

Tahap Desain ini akan membuat gambar desain topologi jaringan interkoneksi yang akan dibangun, diharapkan dengan gambar ini akan memberikan gambaran seutuhnya dari kebutuhan yang ada. Desain bisa berupa desain struktur topologi, desain akses data, desain tata layout perkabelan, dan sebagainya yang akan memberikan gambaran jelas tentang proyek yang akan dibangun.

3. Simulasi/Prototipe

Beberapa teknisi jaringan akan membuat dalam bentuk simulasi dengan bantuan Tools khusus di bidang network seperti BOSON, PACKET TRACERT, NETSIM, dan sebagainya, hal ini dimaksudkan untuk melihat kinerja awal dari jaringa yang akan dibangun dan sebagai bahan presentasi dan sharing dengan team work lainnya.

4. Implementasi

Di tahapan ini akan memakan waktu lebih lama dari tahapan sebelumnya. Dalam implementasi teknisi jaringan akan menerapkan semua yang telah direncanakan dan di desain sebelumnya.

5. Monitoring

Setelah implementasi tahapan monitoring merupakan tahapan yang penting, agar jaringan komputer dan komunikasi dapat berjalan sesuai dengan keinginan dan tujuan awal dari pengguna pada tahap awal analisis, maka perlu dilakukan kegiatan monitoring.

6. Manajemen

Di manajemen atau pengaturan, salah satu yang menjadi perhatian khusus adalah 
masalah aturan, kebijakan perlu dibuat untuk membuat / mengatur agar sistem yang telah dibangun dan berjalan dengan baik dapat berlangsung lama dan unsur reliability terjaga.

\section{Cisco Three-Layered Hierarchical Model}

Cisco telah mendefinisikan sebuah model hirarki yang dikenal sebagai model hirarki internetworking. Model ini membuat topologi jaringan menjadi lebih sederhana, handal, terukur, dan lebih mudah dipahami karena berfokus pada tiga bidang fungsional (Cisco, 2014) yaitu :

1. Core Layer

Lapisan ini dianggap sebagai backbone dari suatu jaringan. Lapisan ini menyediakan struktur transportasi yang teroptimasi dan reliabel dengan meneruskan lalu lintas paket pada kecepatan yang sangat tinggi. Perangkat pada lapisan inti tidak boleh terbebani oleh setiap proses yang menghalangi pengiriman paket kecepatan tinggi. Hal ini ternasuk pengecekan access-list, enkripsi data, dan translasi alamat.

2. Distribution Layer

Lapisan ini termasuk router dan switch layer-3. Lapisan ini juga disebut lapisan Workgroup. Lapisan ini akan membentuk kebijakan jaringan yang digunakan untuk pendekatan dalam menangani beberapa jenis lalu lintas yaitu routing updates, route summaries, lalu lintas VLAN, dan agregasi alamat dalam mengamankan jaringan serta menghemat sumberdaya jaringan dengan membatasi lalu lintas yang tidak perlu. Pada lapisan ini juga akan berlaku proses penggunaan routing protokol, baik satu jenis maupun berbeda jenis (redistribute).

3. Access Layer

Lapisan ini termasuk hub dan switch. Lapisan ini juga disebut lapisan desktop karena berfokus pada menghubungkan node klien, seperti workstation ke jaringan. Lapisan ini memastikan bahwa paket yang dikirim sampai ke pengguna.

\section{HASIL DAN DISKUSI}

\subsection{Kondisi Eksisting Topologi Jaringan PDII-LIPI}

Pada tahap penelitian ini dilakukan proses inventarisasi topologi existing jaringan yang ada di PDII-LIPI. Dalam perancangan topologi jaringan existing terdapat kegiatan sebagai berikut: topologi jaringan kabel dan nirkabel, perangkat yang digunakan, pemetaan letak Access Point (AP) ,dan jangkauan AP. Dengan melakukan proses inventarisasi topologi eksisting ini dapat diketahui kekurangan dan kelebihan infrastruktur jaringan di PDII-LIPI. Tahap ini merupakan tahap analisis dari metode NDLC. Metode NDLC digunakan untuk membangun sebuah jaringan komputer termasuk topologi pada suatu instansi yang menggunakan teknologi untuk komunikasi dan pertukaran informasi (Fathinudin $\&$ Teguh, 2014).

\section{Topologi Jaringan kabel dan nirkabel}

PDII-LIPI sudah memiliki infrastruktur jaringan yang membantu karyawan untuk saling bertukar informasi dan membantu karyawan dalam memberikan akses ke informasi ilmiah sebagai salah satu fungsi kerja dari PDII-LIPI. Jaringan pada PDII-LIPI digambarkan sebagai berikut. 


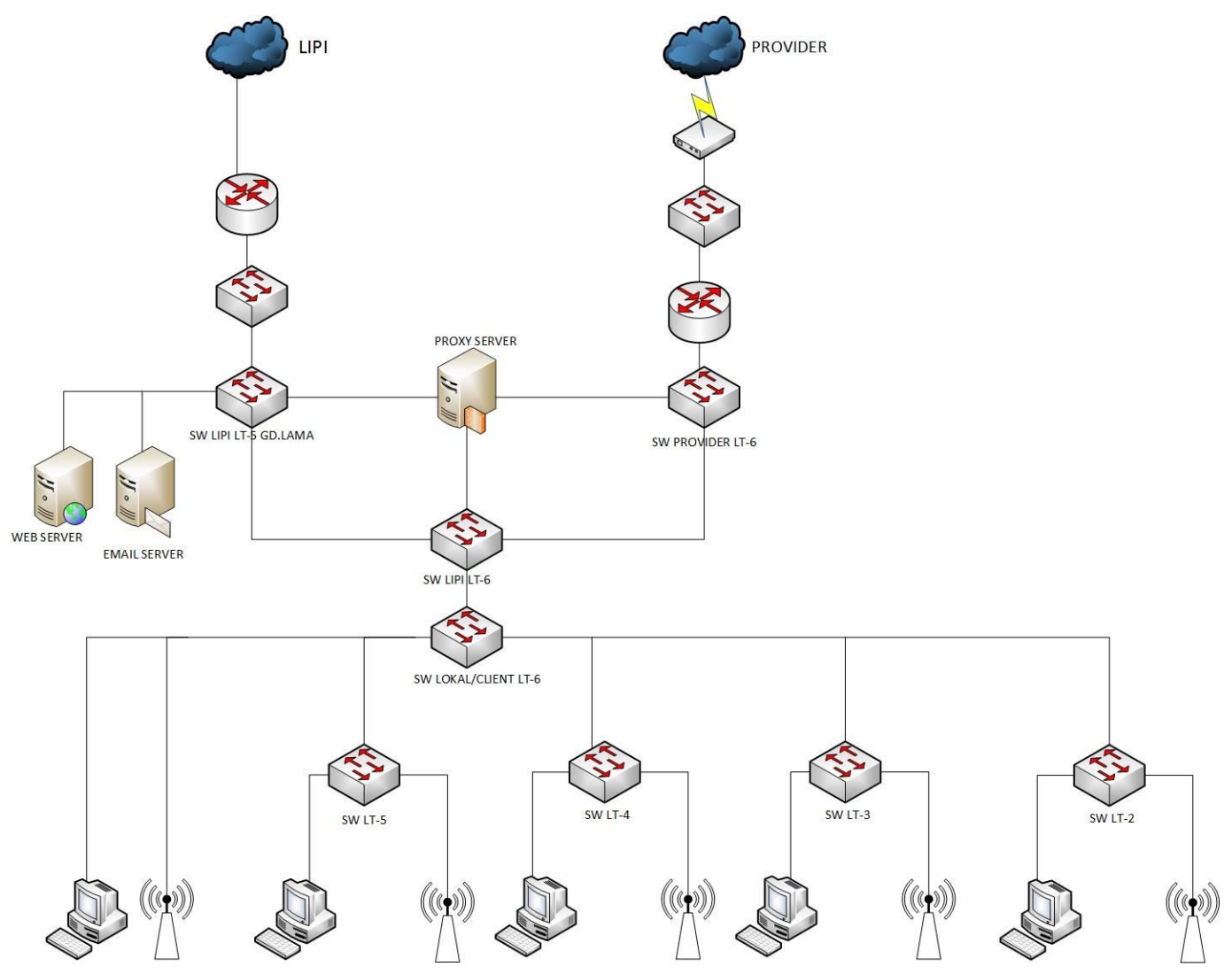

Gambar 2. Topologi Infrastrukur Jaringan Kabel dan Nirkabel Eksisting

Pada saat ini PDII-LIPI menggunakan dua akses internet yaitu dari LIPI dan provider. Kedua koneksi tersebut digunakan oleh karyawan maupun pengunjung PDII-LIPI untuk mengakses internet. Akses internet dari LIPI digunakan sebagai koneksi utama untuk menangani kegiatan yang ada di PDII-LIPI seperti untuk penyimpanan informasi ilmiah dan jurnal. Sementara akses internet dari provider digunakan untuk kegiatan browsing dan tukar menukar jurnal oleh pegawai PDII-LIPI. Berikut beberapa kekurangan untuk topologi saat ini yang didapat dari hasil wawancara dan observasi lapangan.

1) Belum terlihat jelas model hirarki jaringannya / Pemetaan yang lebih mendetil.

2) Belum adanya monitoring dari pegawai PDII-LIPI secara berkala terhadap topologi jaringan pada saat ini

3) jaringan di PDII-LIPI belum redundant

4) belum adanya pemetaan ip (internet protocol) secara detil

5) Belum adanya pembagian bandwidth / manajemen bandwidth

6) Sering terjadinya kegagalan koneksi internet yang disebabkan oleh jaringan utama yang mati dalam hal ini jaringan dari LIPI dan provider, selain itu karena perangkat switch utama yang mengalami masalah atau jalur dari switch utama ke switch tiap lantai terputus padahal sudah menggunakan dua layanan jaringan internet yang berbeda.

\section{Perangkat yang digunakan}

Perangkat jaringan yang digunakan di PDII-LIPI antara lain adalah switch, router dan Access Point. Berikut ini adalah spesifikasi perangkat jaringan yang digunakan di gedung PDII-LIPI. 
Desain Topologi Jaringan Kabel Nirkabel PDII-LIPI dengan Cisco Three-Layered Hierarchical menggunakan NDLC

Tabel 2. Perangkat Jaringan Eksisting yang digunakan oleh PDII-LIPI

\begin{tabular}{|l|l|l|}
\hline No & Nama Perangkat & Jenis Perangkat \\
\hline 1 & Router MikroTIK RB1100AHx2 & Router \\
\hline 2 & Switch TRENDnet TEG-S16g & Switch \\
\hline 3 & Switch Cisco Catalyst 2950 Series & Switch \\
\hline 4 & Cisco SF90-24 24-Port 10/100 Switch & Switch \\
\hline 5 & TP-LINK TL-SF1024D Switch & Switch \\
\hline 6 & D-LINK DES-1024A Switch & Switch \\
\hline 7 & D-LINK 1016D 10/100 FaE. & Switch \\
\hline 8 & $\begin{array}{l}\text { Linksys Wireless-G Broadband Router Model } \\
\text { WRT54GL version 1.1 }\end{array}$ & Access Point \\
\hline
\end{tabular}

Berdasarkan Tabel 2 bahwa dari segi perangkat sudah cukup memadai, hanya ada beberapa kekurangan terutama di Access Point yaitu hanya mendukung 802.11b dan $802.11 \mathrm{~g}$ saja dengan kecepatan maksimum transfer datanya sebesar 54Mbps. Sedangkan saat ini sudah banyak perangkat yang mendukung 802.11 , 802.11ac bahkan 802.11ag.

\section{Pemetaan Access Point}

Dengan menggunakan denah bangunan yang sudah dibuat maka dilakukan pemetaan lokasi AP pada setiap lantai di PDII-LIPI. Pemetaan ini dilakukan dengan survei langsung ke PDII-LIPI dan mencatat setiap data dari AP seperti MAC Address dan SSID. Berikut adalah letak AP lantai 2-lantai 6 PDII-LIPI :

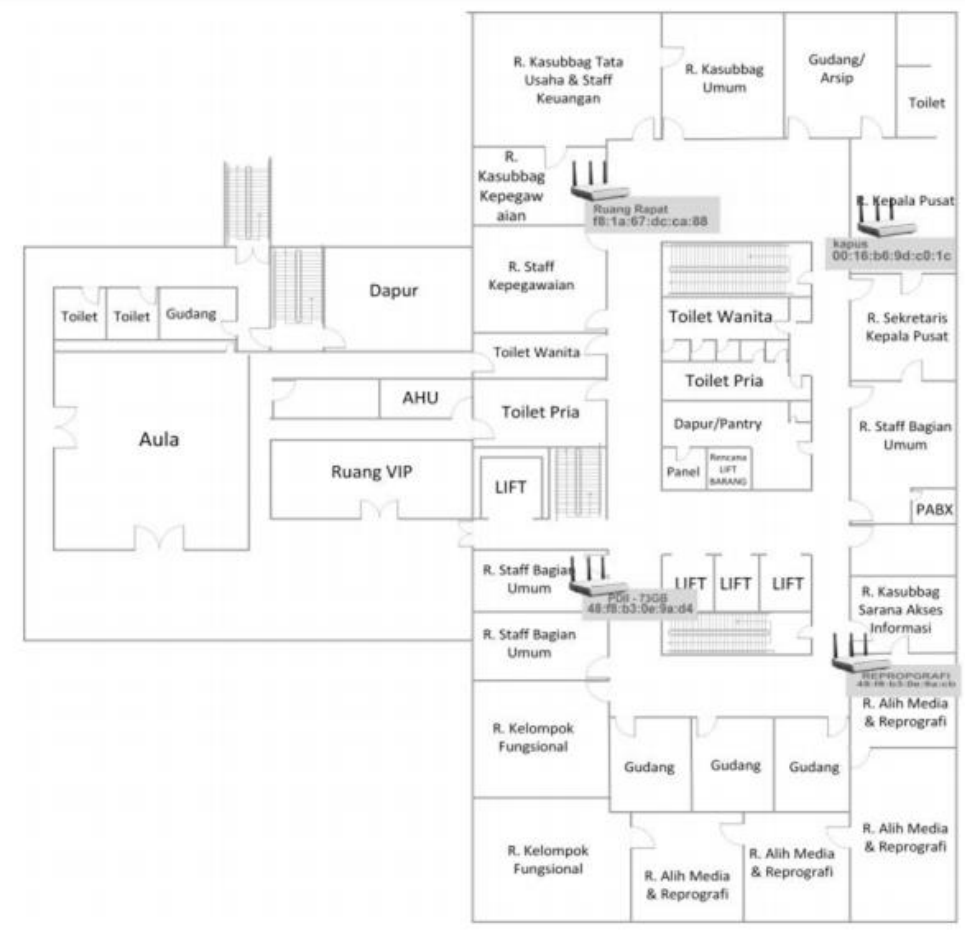

Gambar 3. Lokasi Access Point di Lantai 2 


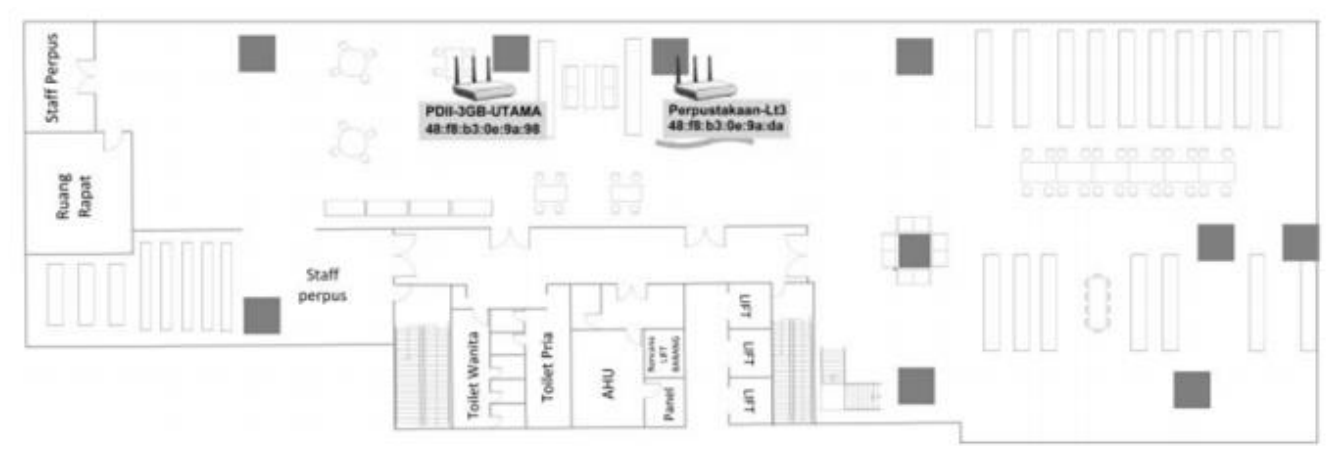

Gambar 4. Lokasi Access Point Lantai 3

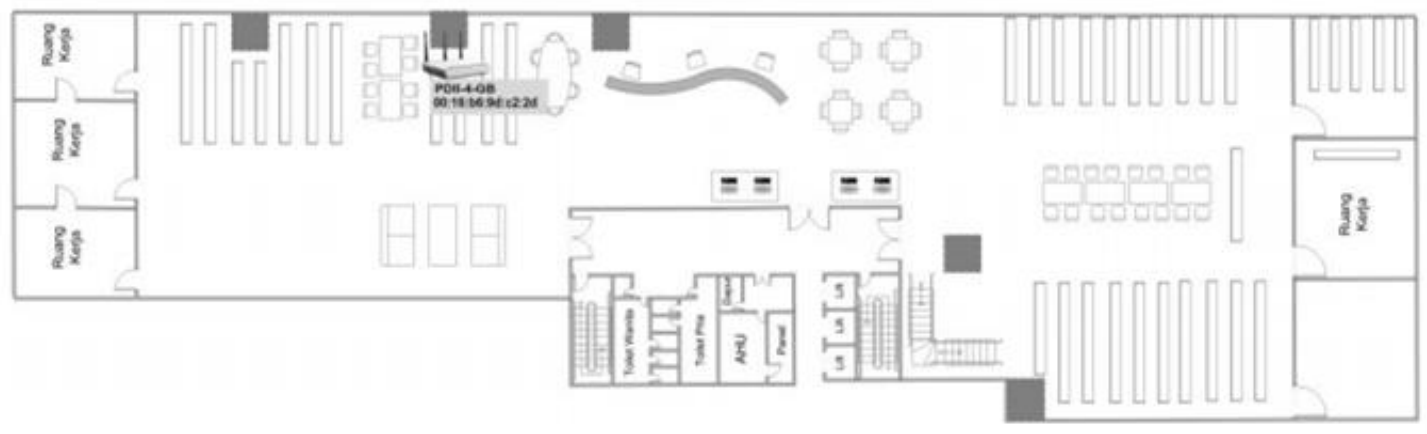

Gambar 5. Lokasi Access Point Lantai 4

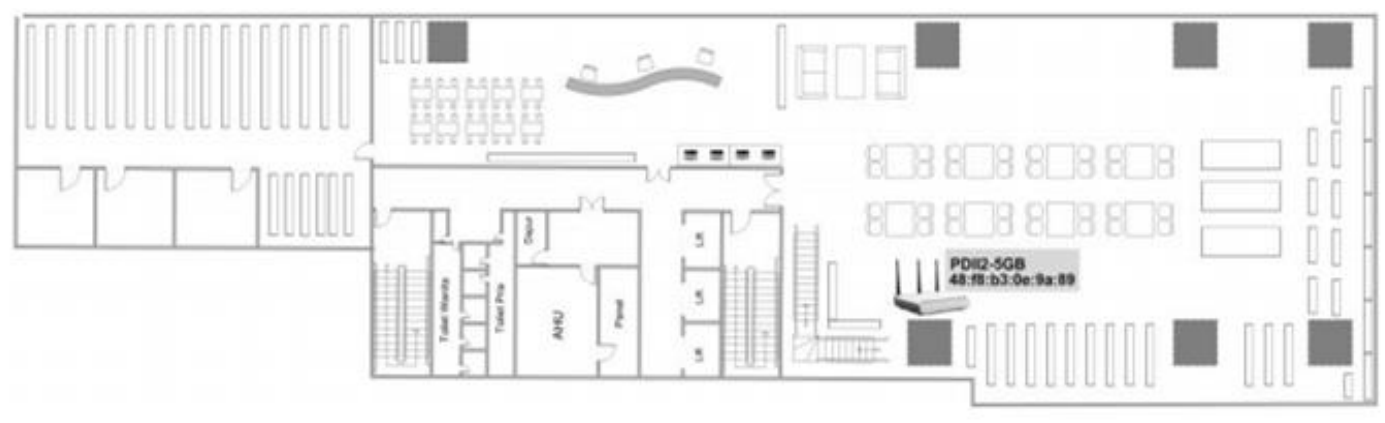

Gambar 6. Lokasi Access Point Lantai 5

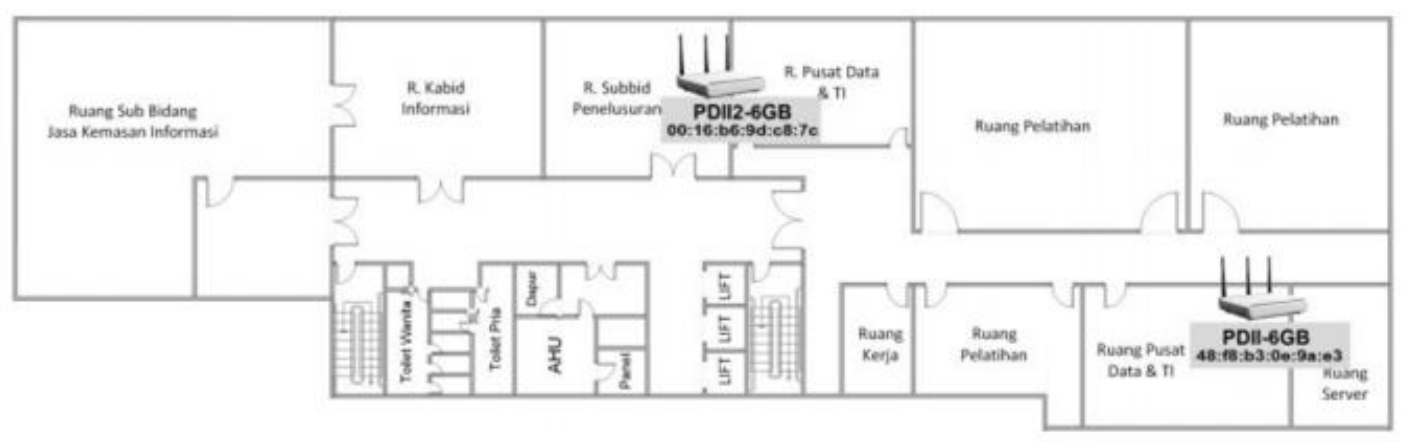

Gambar 7. Lokasi Access Point Lantai 6 


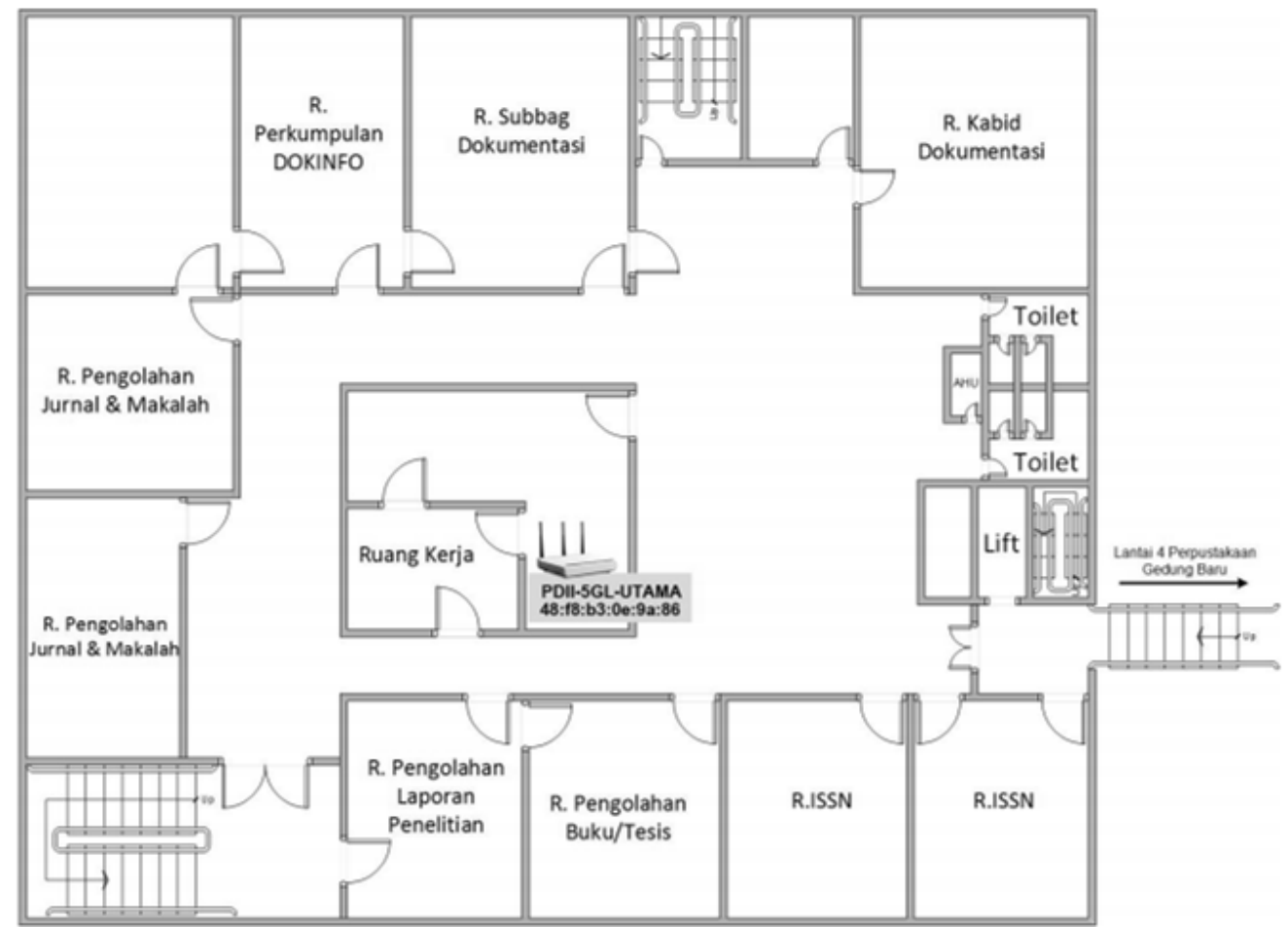

Gambar 8. Lokasi Access Point Lantai 5 Lama

Dilihat dari Gambar 3, 4, dan 5 jumlah Access Point masih kurang dan belum tersebar secara merata di setiap lantai, apalagi saat ini banyak karyawan atau pengunjung yang mengakses internet dari mobile device sehingga ini menjadi kendala dalam mendukung proses bisnis yang ada di PDII-LIPI.

\section{Jangkauan Access Point}

Setelah mengetahui jumlah dan lokasi AP maka selanjutnya dilakukan pengukuran penyebaran sinyal dari AP yang ada di gedung PDII-LIPI. Pengukuran ini dilakukan dengan menggunakan aplikasi Heat Mapper. Agar aplikasi dapat berfungsi dengan baik maka harus di install pada perangkat yang mempunyai wireless card sehingga dapat menangkap sinyal dari Access Point.

Aplikasi Heat Mapper membutuhkan denah lokasi yang akan diukur, denah ini dapat berupa file gambar dengan format .jpeg atau .png. Jika sudah mempunyai denah lokasi yang akan diukur masukkan ke dalam aplikasi Heat Mapper agar dapat langsung dilakukan pengukuran. Melakukan pengukuran dengan berjalan mengelilingi ruangan dan me-klik pada denah yang sudah dimasukkan ke dalam Heat Mapper. Hasilnya akan muncul tanda panah sesuai dengan rute yang sudah dilalui saat melakukan pengukuran. Setelah mengelilingi ruangan dan kembali ke titik awal pengukuran maka Heat Mapper akan menunjukkan jangkauan sinyal tiap AP pada lokasi tersebut.

Berikut adalah peta jangkauan Access Point kondisi eksisting mulai lantai 2 dan sampai lantai 6. 


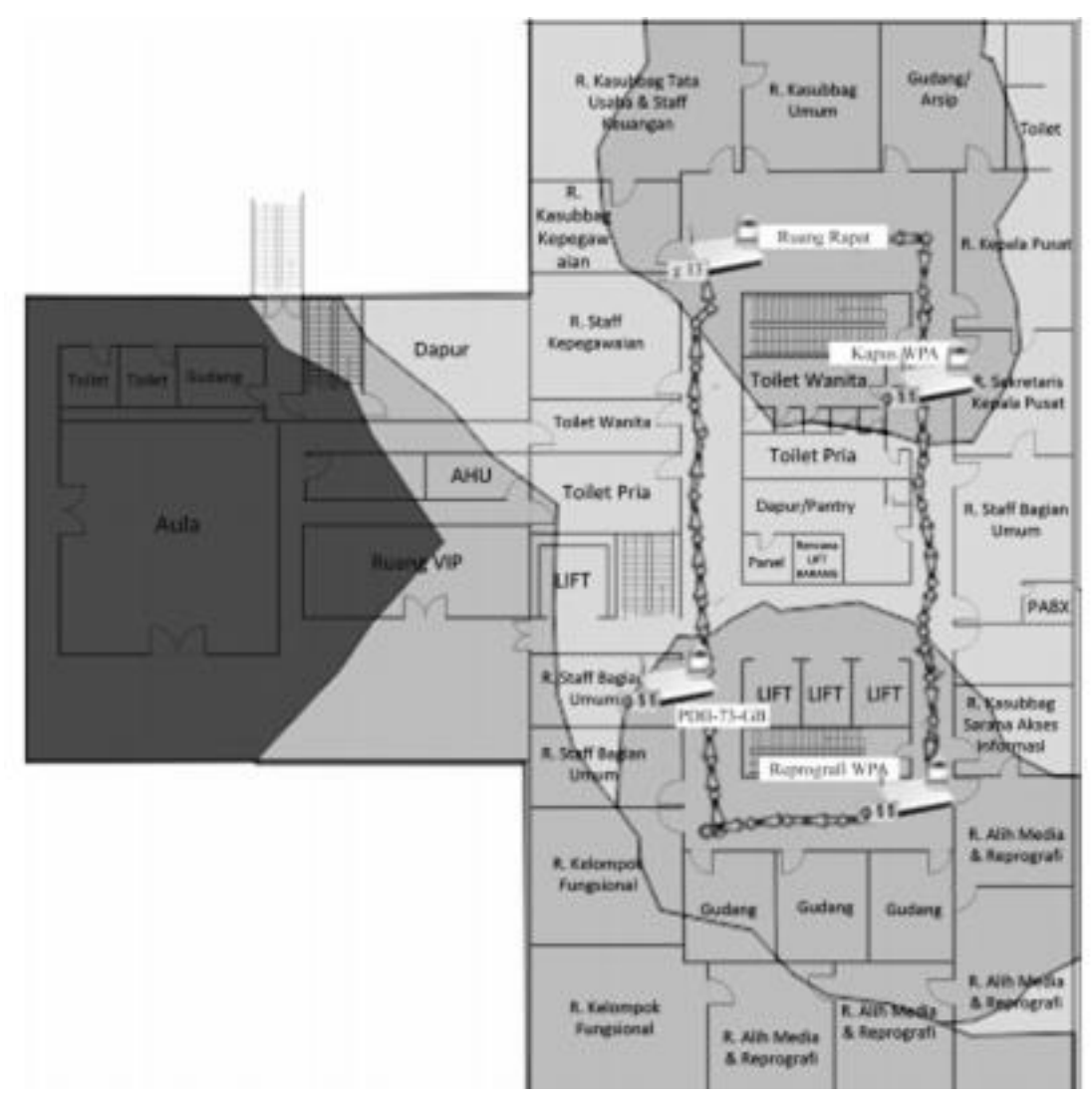

Gambar 9. Jangkauan Access Point Lantai 2

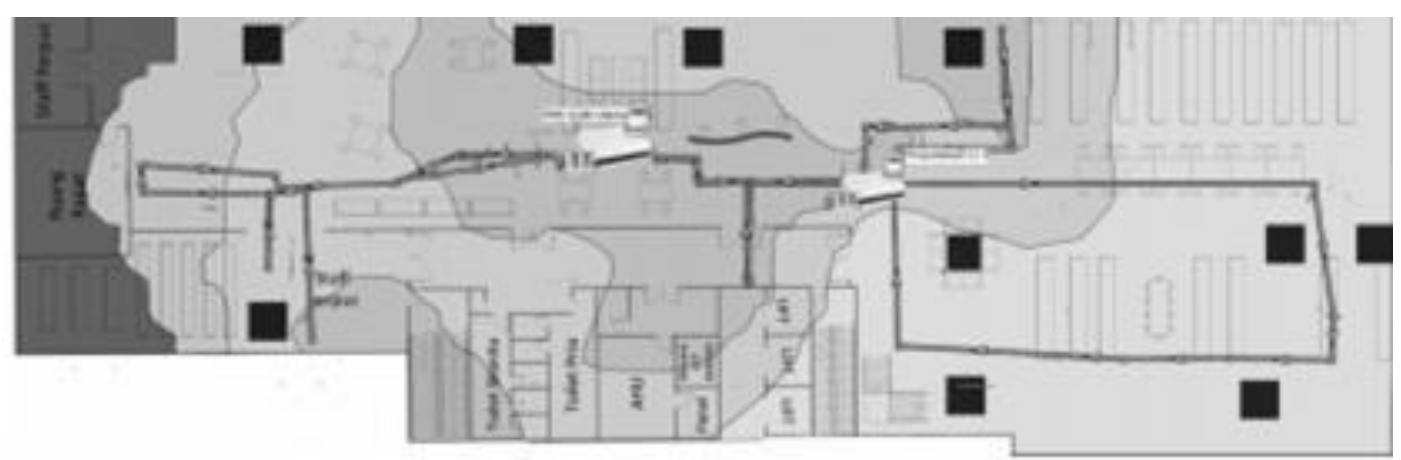

Gambar 10. Jangkauan Access Point Lantai 3

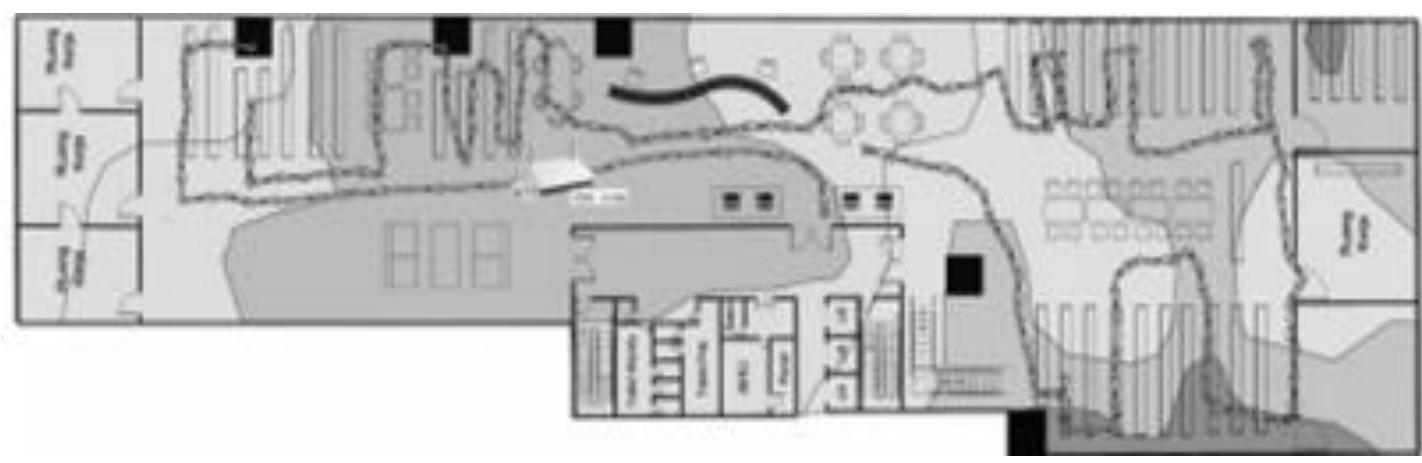

Gambar 11. Jangkauan Access Point Lantai 4 


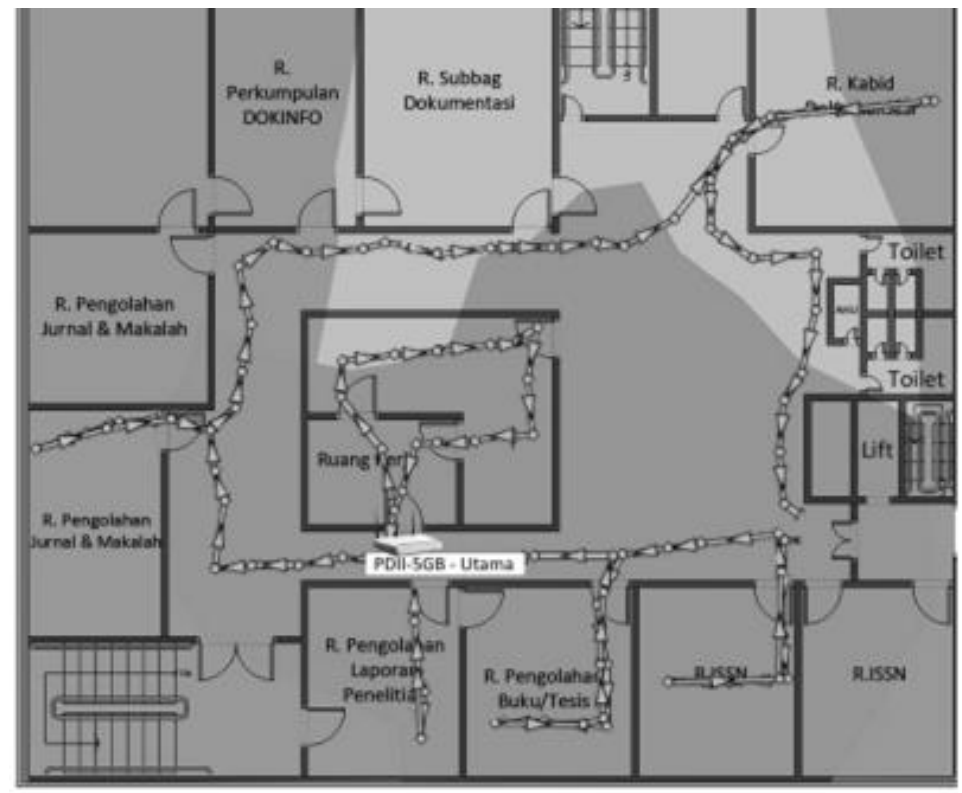

Gambar 12. Jangkauan Access Point Lantai 5 Lama

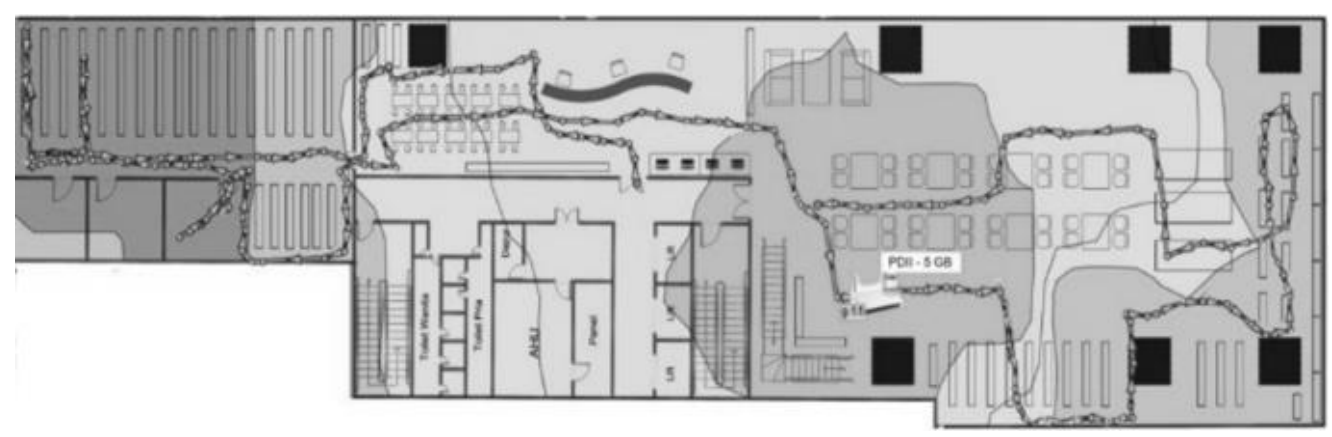

Gambar 13. Jangkauan Access Point Lantai 5

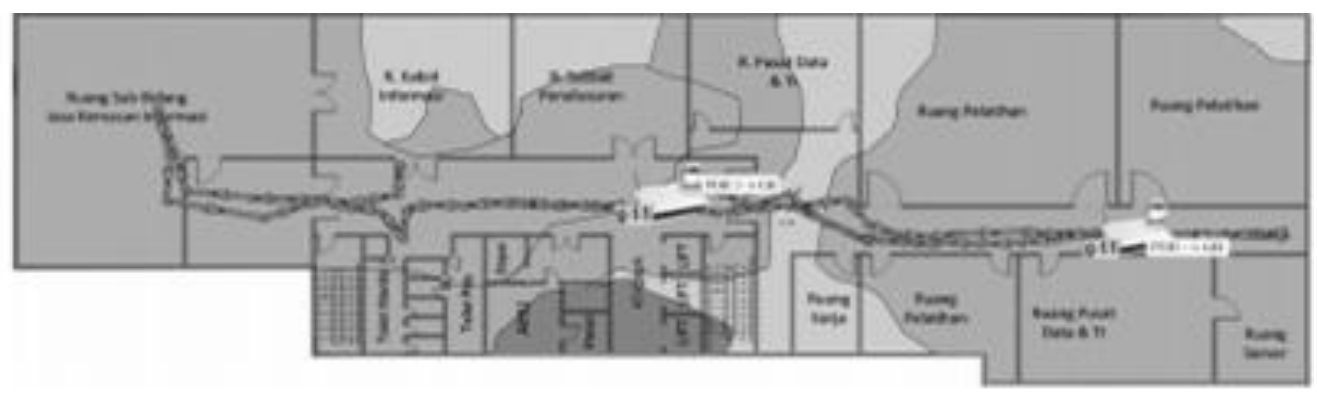

Gambar 14. Jangkauan Access Point Lantai 6

Warna pada gambar memperlihatkan kualitas sinyal warna abu-abu muda memiliki arti kualitas sinyal kuat atau bagus. Warna abu tua sampai warna abu pekat menandakan sinyal lemah atau kurang kuat. Warna abu pekat sampai hitam menandakan sinyal sangat lemah atau tidak mendapat sinyal sama sekali. Dari gambar 6 terlihat bahwa jangkauan sinyal access point di setiap lantai tidak merata hal ini ditandai dengan masih adanya daerah yang berwarna abu muda sampai hitam pada daerah ruang kerja karyawan PDII-LIPI yang menandakan daerah tersebut mendapatkan kualitas sinyal yang lemah atau kurang kuat. Hal ini disebabkan beberapa hal yaitu, jumlah AP yang masih kurang dan peletakan Access Point yang kurang tepat, misal di bawah meja karyawan. 


\subsection{Usulan Topologi Jaringan PDII-LIPI}

Dalam perancangan topologi jaringan usulan terdapat topologi jaringan, perangkat yang akan digunakan di PDII-LIPI, pemetaan letak AP (Access Point) Usulan, dan pengujian jangkauan AP usulan. Usulan ini didapat dari hasil analisa topologi eksisting jaringan sebelumnya. Tahapan ini merupakan tahapan desain pada metode NDLC. PDII-LIPI sudah memiliki infrastruktur jaringan yang membantu karyawan untuk saling bertukar informasi dan membantu karyawan dalam memberikan akses ke informasi ilmiah sebagai salah satu fungsi kerja dari PDII-LIPI. Namun, pada topologi eksisting belum memiliki pemetaan jaringan yang sesuai dengan keadaan perangkat jaringan yang ada. Berikut adalah desain topologi jaringan komputer usulan untuk mendukung proses bisnis PDII-LIPI.

\subsubsection{Topologi Jaringan kabel dan nirkabel Usulan}

Untuk topologi jaringan usulan terbagi menjadi dua walaupun masih ada irisan dari kedua topologi tersebut. Yang membedakan adalah ujung dari pengguna atau user. Berikut adalah topologi usulan untuk infrastruktur jaringan menggunakan standar Cisco Three-Layered Hierarchical Model.

\section{Topologi Jaringan Kabel}

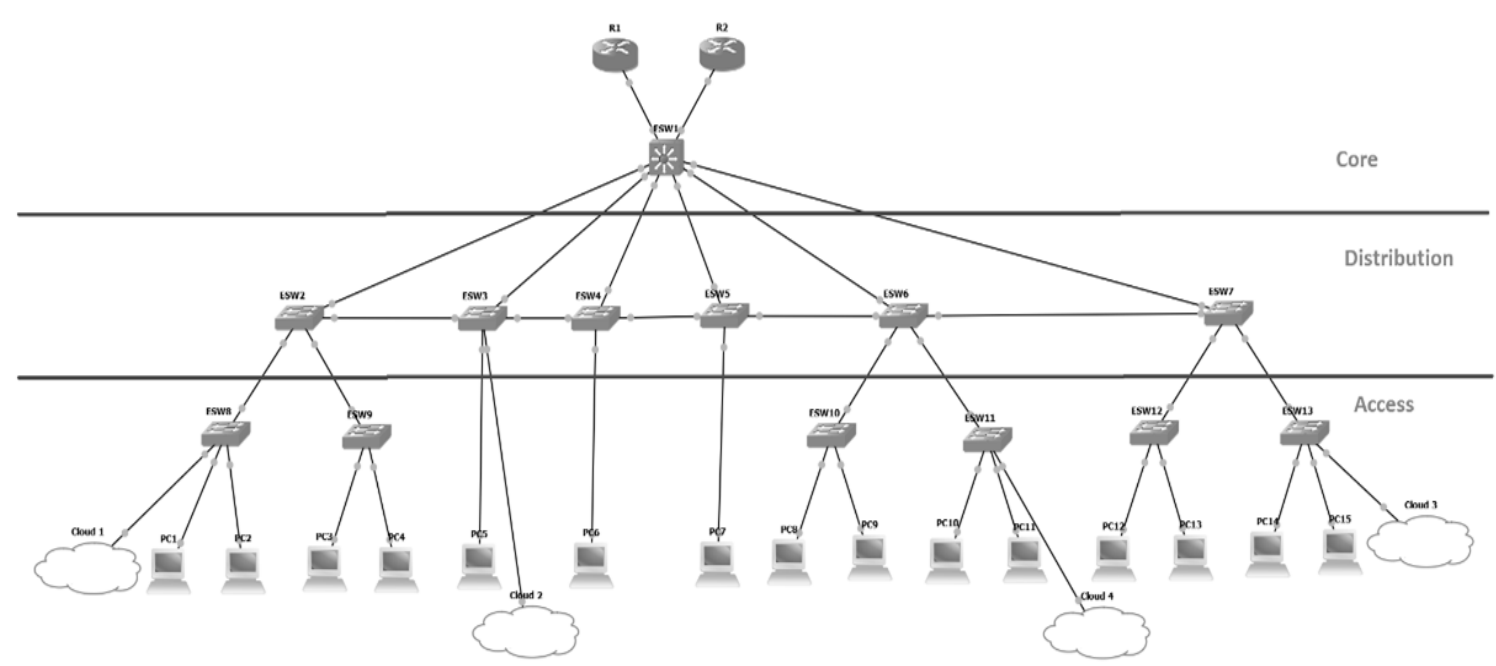

Gambar 15. Tolopogi Jaringan Kabel Usulan

Pada perancangan desain topologi jaringan usulan digunakan konsep Cisco Three-Layered Hierarchial Model yang terdiri dari lapisan Core, lapisan Distribution dan lapisan Access. Hal ini bertujuan untuk membagi perangkat jaringan yang berkerja agar sesuai dengan fungsinya dalam berkomunikasi dengan masing-masing perangkat. Pemilihan dan penempatan perangkat jaringan secara tepat merupakan salah satu faktor penting dalam membangun sebuah jaringan komputer.

Selain itu, pada jaringan usulan sudah menggunakan konsep redundant, sehingga jika ada jalur yang putus dapat di backup oleh jalur yang lain. Selain itu pada jaringan usulan ditambahkan penggunaan VLAN untuk setiap pengguna di PDII-LIPI yang bertujuan agar keamanan data dapat terjamin sehingga sudah dapat mengklasifikasi jenis pengguna sesuai dengan pengaturan yang diinginkan. 
Lapisan core pada jaringan usulan menggunakan dua router dan 1 multilayer switch yang akan berfungsi untuk mengatur koneksi yang akan diberikan ke layer dibawahnya untuk diteruskan ke pengguna. Router pada lapisan core akan terhubung ke dua jaringan internet yang digunakan oleh PDII-LIPI yaitu koneksi dari dan provider.

Kemudian pada lapisan distribution terdapat enam switch yang akan ditempatkan di setiap lantai. Switch tersebut berperan sebagai switch utama di setiap lantai yang akan meneruskan akses dari pengguna akhir ke internet. Dan lapisan access menghubungkan pengguna dengan switch yang ada di lapisan distribution. Terdapat pula beberapa switch di lapisan access yang terhubung dengan Access Point dan PC. Akan tetapi untuk lantai 3, 4, dan 5 PDII-LIPI switch pada lapisan distribution akan terhubung dengan Access Point, PC, dan server.

\section{Topologi Jaringan Nirkabel}

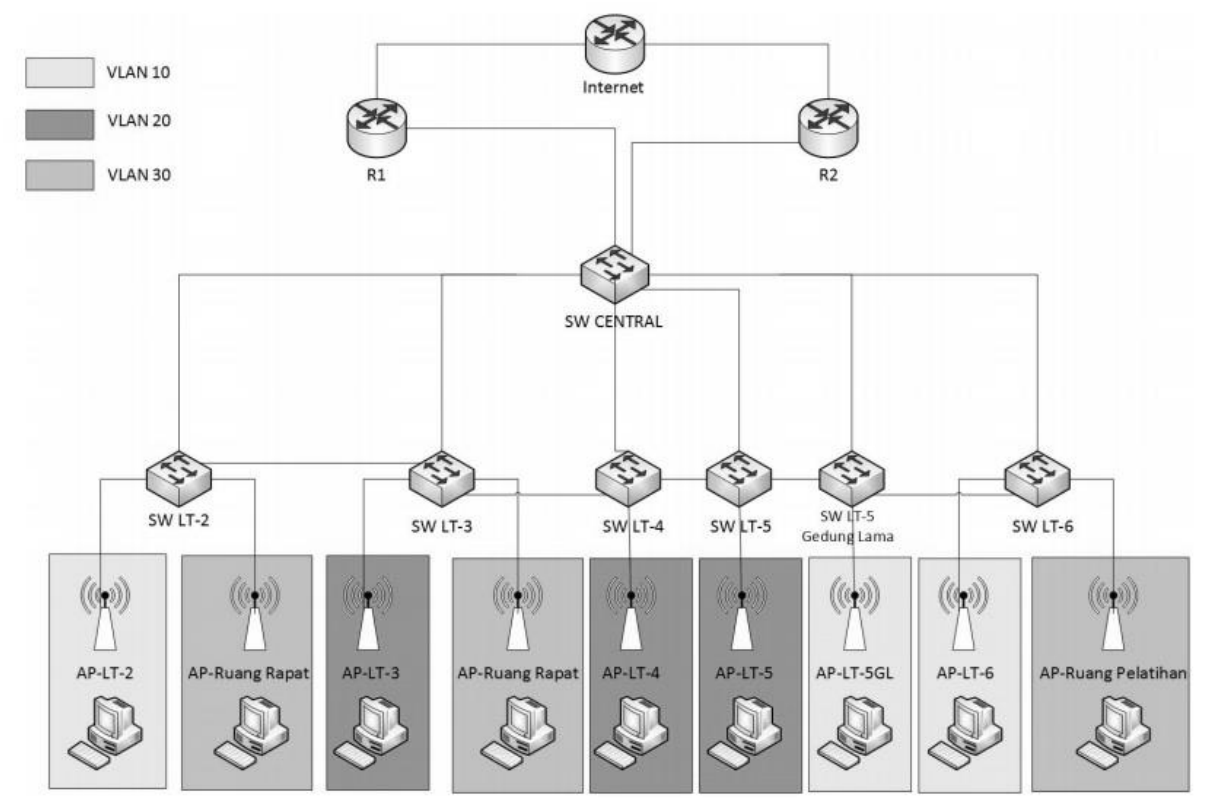

Gambar 16. Topologi Jaringan Nirkabel Usulan

Desain jaringan wireless usulan seperti pada Gambar 8 digambarkan berdasarkan model hirarki internetworking atau yang disebut Cisco Three-Layered Hierarchical Model.

Router 1(R1), Router 2 (R2) dan Switch Central pada Gambar 8 merupakan lapisan Core pada jaringan nirkabel usulan,R1 dan R2 dihubungkan langsung dengan dua jaringan yang ada di PDII-LIPI yaitu jaringan dari LIPI dan jaringan dari provider. Selanjutnya, R1 dan R2 terhubung dengan switch Central yang bertugas untuk mendistribusikan jaringan ke tiap switch yang ada di setiap lantai di gedung PDII-LIPI.

Pada lapisan Distribution digambarkan 6 (enam) buah switch yang mempunyai tugas untuk mendistribusikan jaringan yang didapat dari Switch Central ke Access Point yang terdapat di setiap lantai di gedung PDII-LIPI. Pada lapisan Access digambarkan Access Point untuk mendistribusikan jaringan ke end user. Access Point yang terdapat di setiap lantai menggambarkan VLAN yang terdapat pada gedung PDII-LIPI. Selain itu access point yang digambarkan hanya mewakili dari jumlah Access Point dengan VLAN yang sama pada setiap lantai. 


\subsubsection{Perangkat yang digunakan Usulan}

Untuk perangkat jaringan usulan tidak jauh berbeda dengan perangkat yang sudah dimiliki oleh PDII-LIPI. Mengingat perangkat tersebut sudah cukup mendukung dalam infrastruktur jaringan. Hanya untuk Access Point nirkabel diganti dengan Netgear AC750 Wifi Router yang dapat mendukung wifi jenis $802.11 \mathrm{a} / \mathrm{b} / \mathrm{g} / \mathrm{n} / \mathrm{ac}$.

\subsubsection{Pemetaan Access Point Usulan}

Perancangan pemetaan access point dilakukan berdasarkan kebutuhan user dan untuk memperbaiki kekurangan jaringan eksisting dimana jangkauan sinyal pada jaringan eksisting belum merata, maka dilakukan perancangan pemetaan Access Point yang baru. Perancangan desain jaringan nirkabel usulan dilakukan dengan dua pendekatan yaitu penambahan perangkat baru dan peletakkan lokasi Access Point yang baru. Berikut adalah pemetaan lokasi Access Point usulan. Tahapan ini merupakan tahapan simulasi/prototype pada metode NDLC.

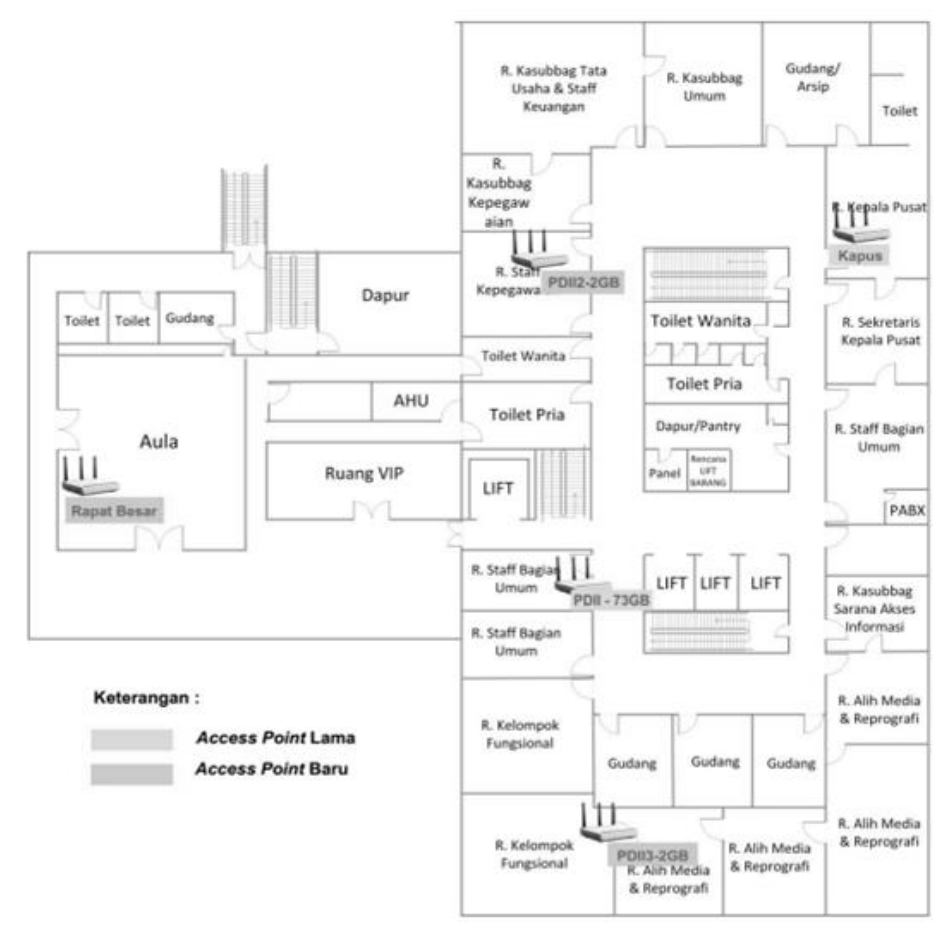

Gambar 17. Letak Access Point Usulan di Lantai 2

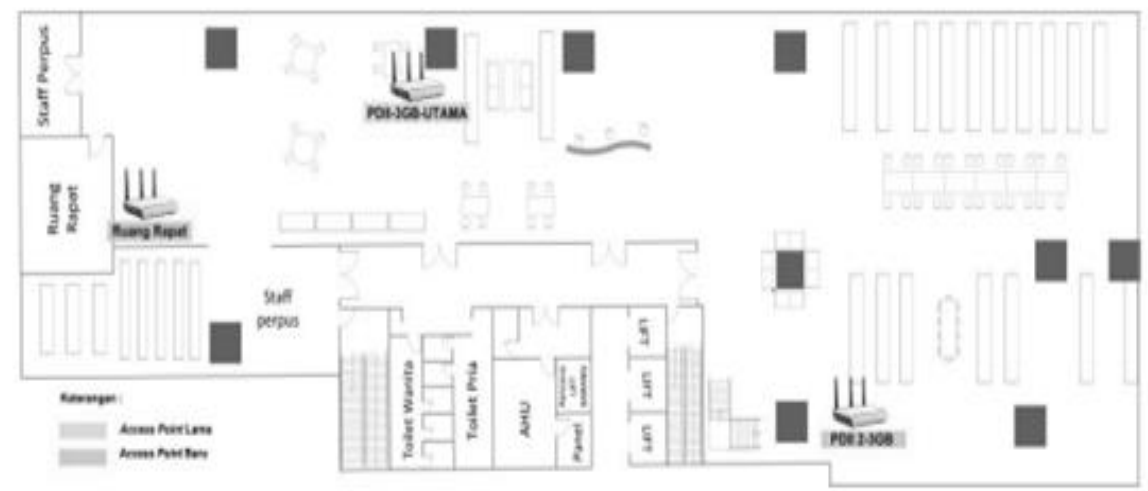

Gambar 18. Letak Access Point Usulan di Lantai 3

Jurnal ELKOMIKA - 60 
Desain Topologi Jaringan Kabel Nirkabel PDII-LIPI dengan Cisco Three-Layered Hierarchical menggunakan NDLC

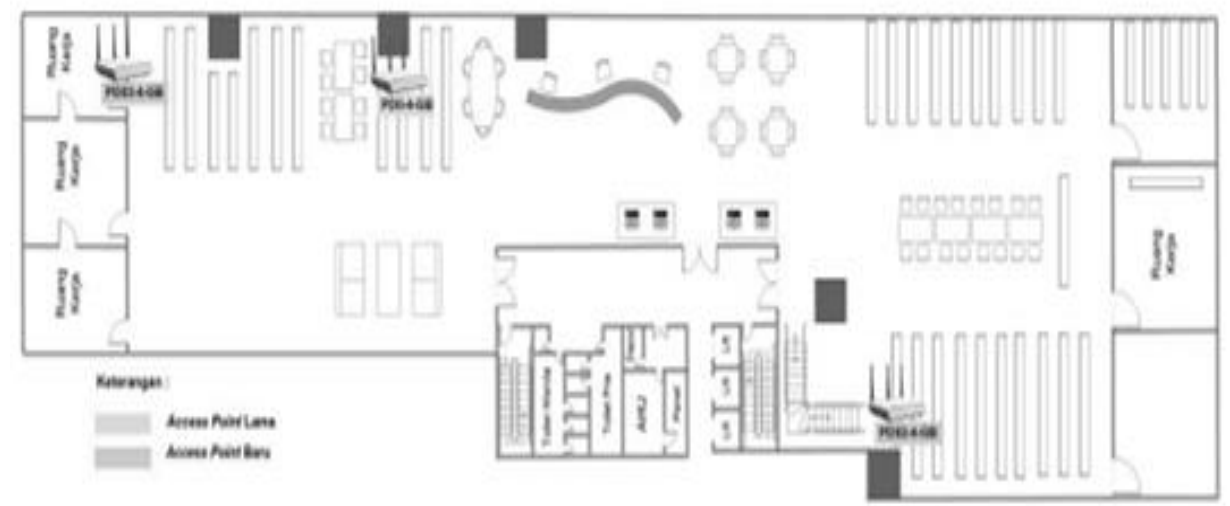

Gambar 19. Letak Access Point Usulan di Lantai 4

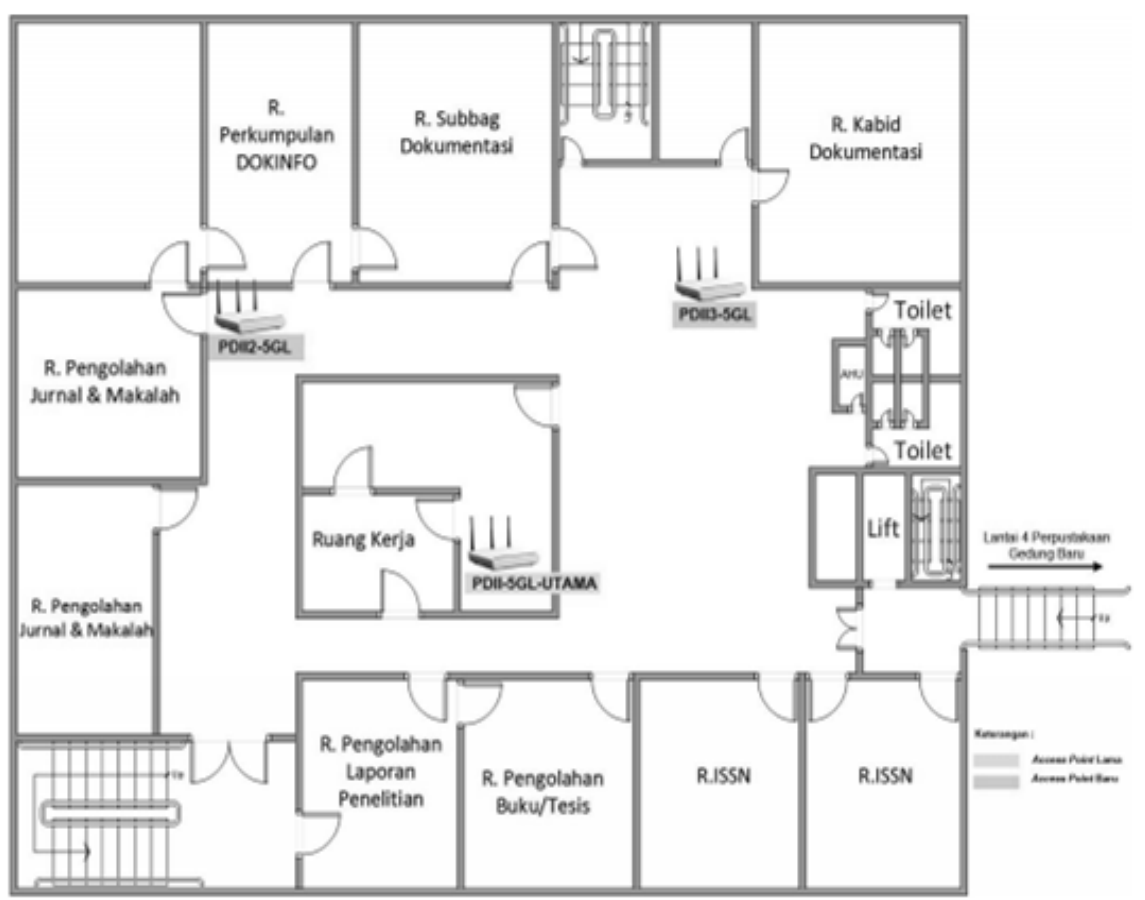

Gambar 20. Letak Access Point Usulan di Lantai 5 Lama

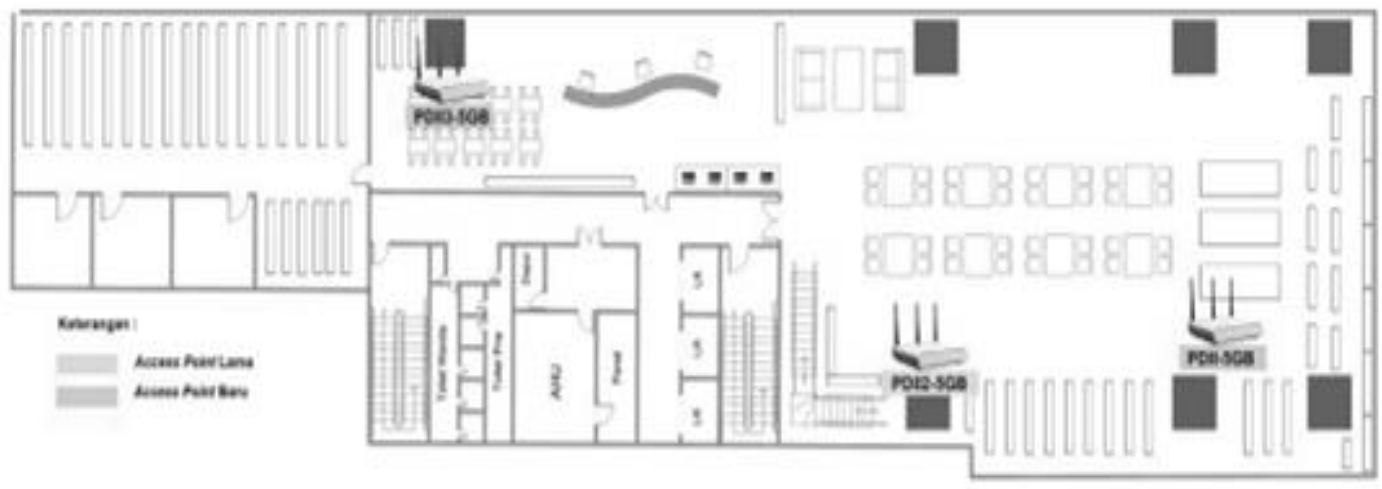

Gambar 21. Letak Access Point Usulan di Lantai 5 


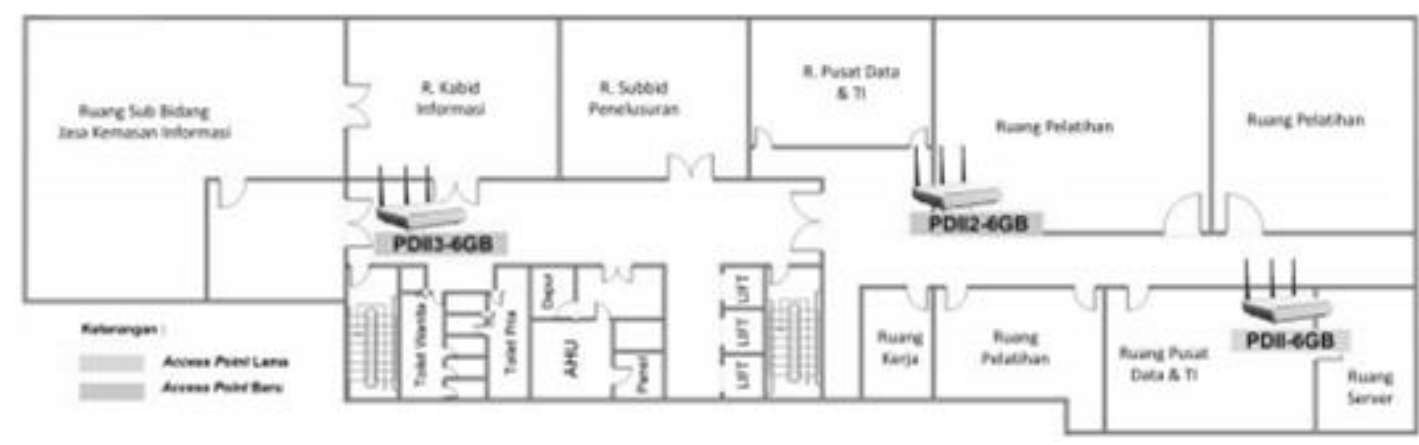

Gambar 22. Letak Access Point Usulan di Lantai 6

Dan untuk mengetahui desain jaringan nirkabel usulan seperti gambar 9 dapat memberikan kualitas sinyal yang optimal maka dilakukan pengujian perangkat access point dengan lokasi masing-masing.

\subsubsection{Jangkauan Access Point Usulan}

Setelah melakukan perancangan jaringan nirkabel usulan dilakukan pengukuran sebaran sinyal dari Access Point sesuai dengan letak Access Point yang diusulkan. Pengukuran sebaran sinyal menggunakan aplikasi Heat Mapper dengan warna abu muda menandakan bahwa kualitas sinyal yang diterima kuat, sedangkan warna abu tua sampai menuju ke warna hitam menunjukkan bahwa kualitas sinyal yang diterima lemah. Berikut adalah hasil yang didapatkan dari pengukuran sebaran sinyal :

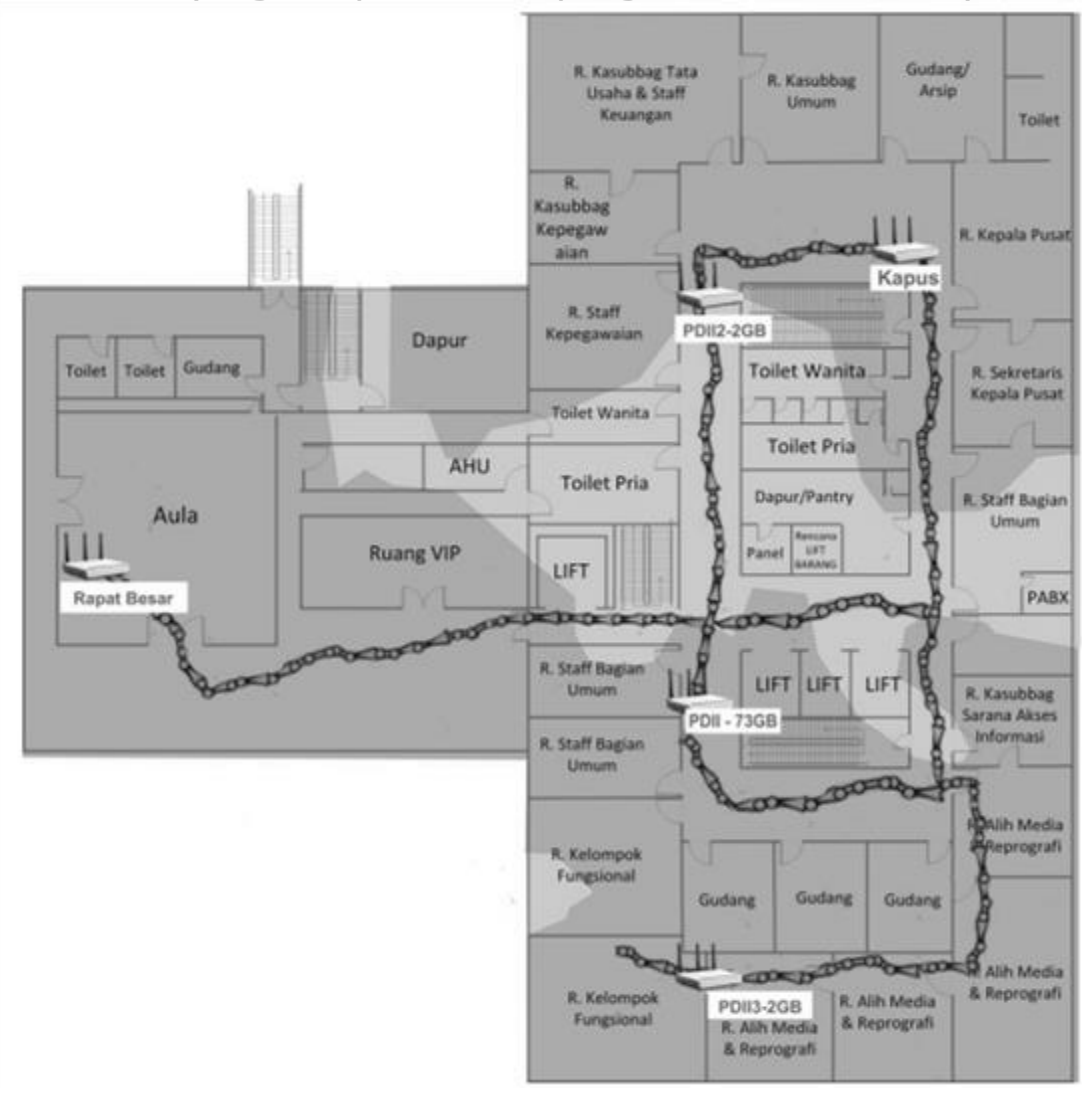

Gambar 23. Jangkauan Sinyal Access Point Usulan di Lantai 2 


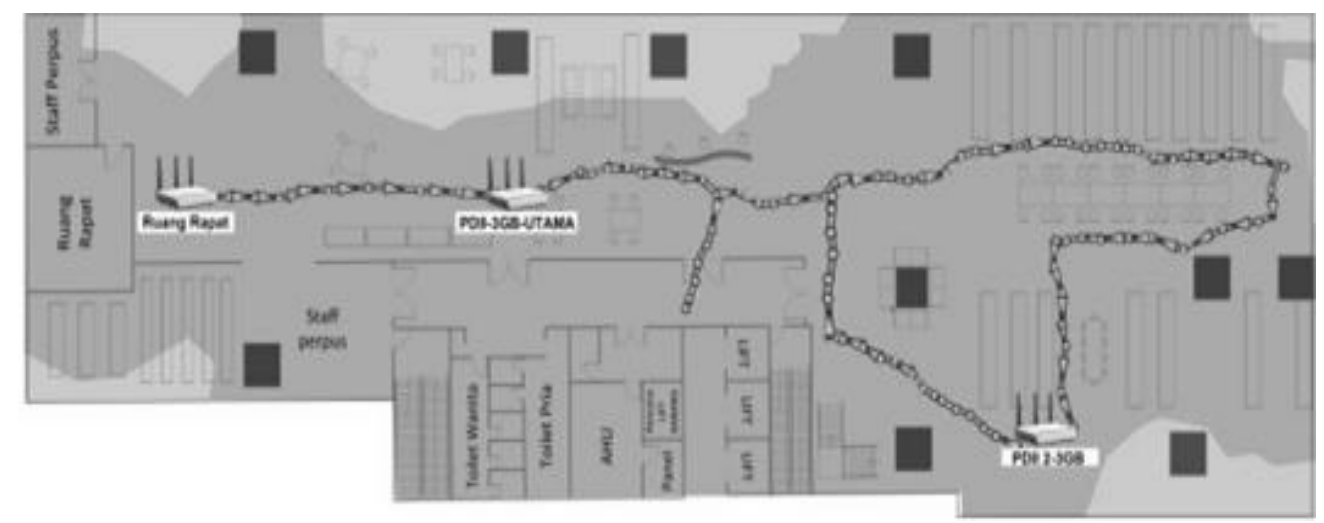

Gambar 24. Jangkauan Sinyal Access Point Usulan di Lantai 3

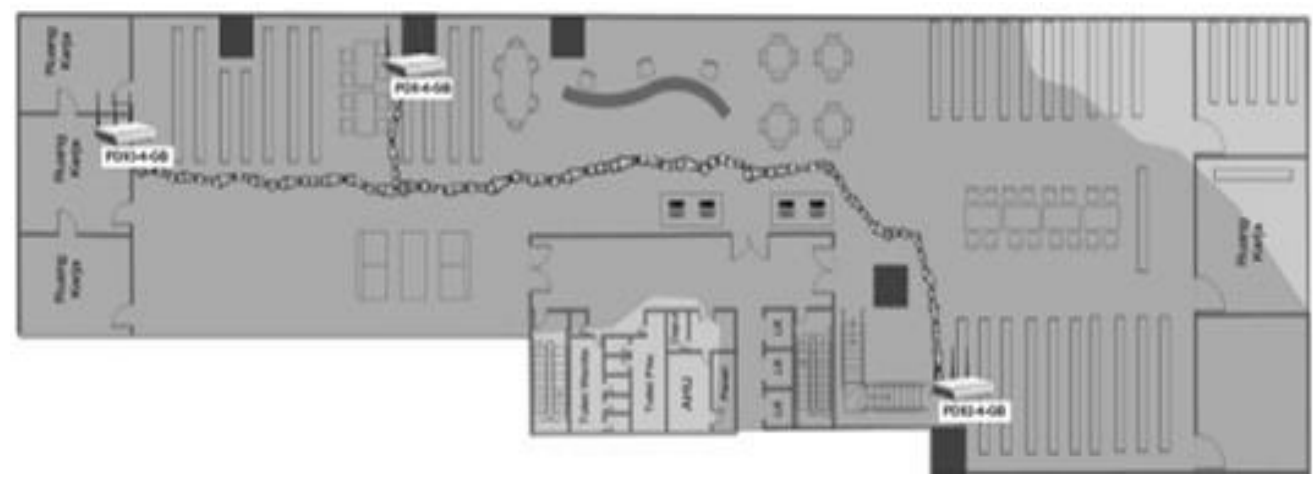

Gambar 25. Jangkauan Sinyal Access Point Usulan di Lantai 4

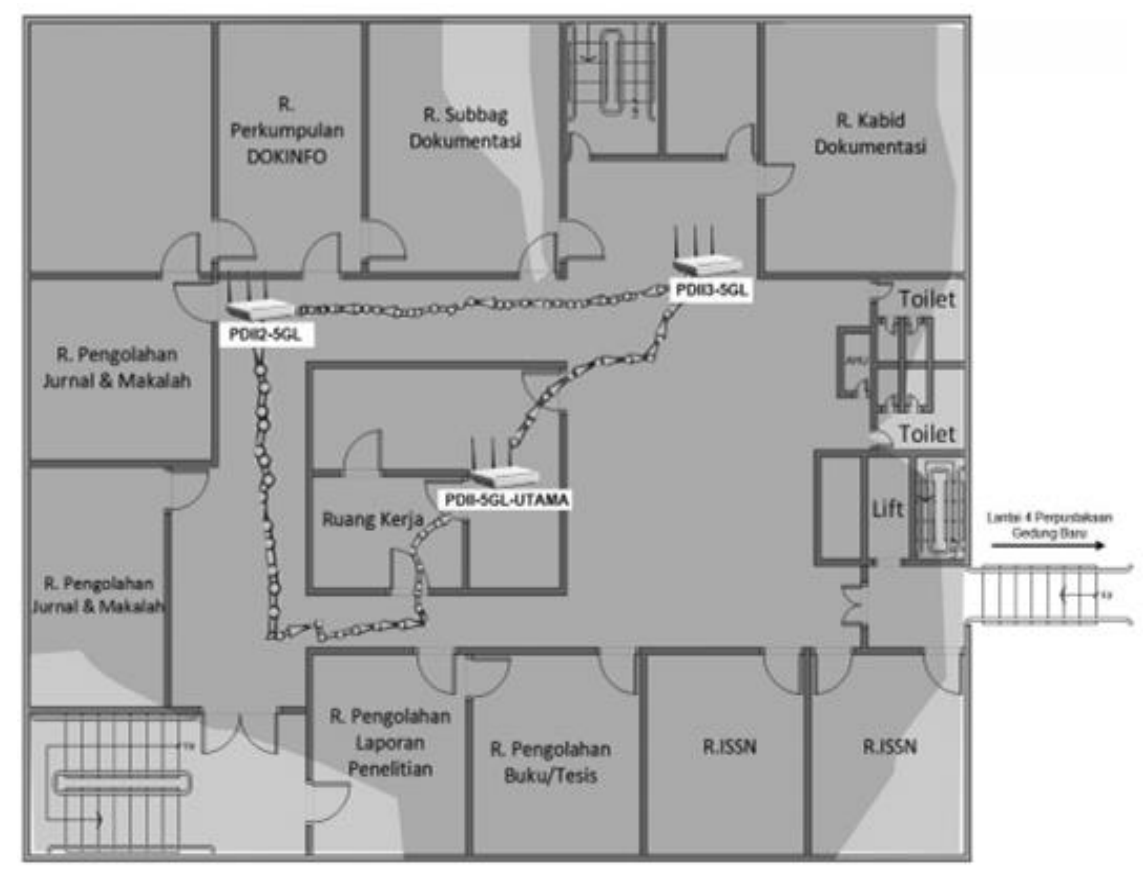

Gambar 26. Jangkauan Sinyal Access Point Usulan di Lantai 5 Lama 


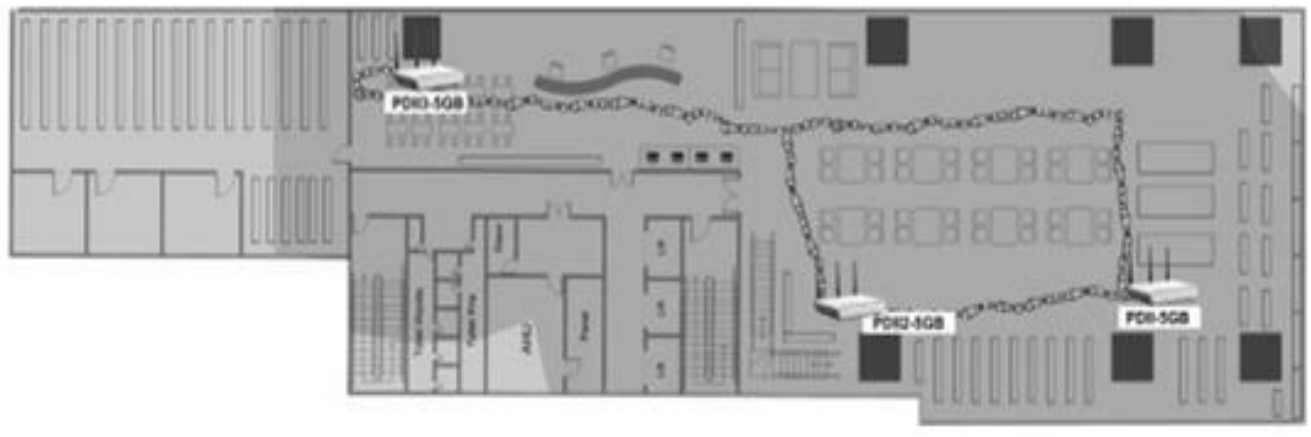

Gambar 27. Jangkauan Sinyal Access Point Usulan di Lantai 5

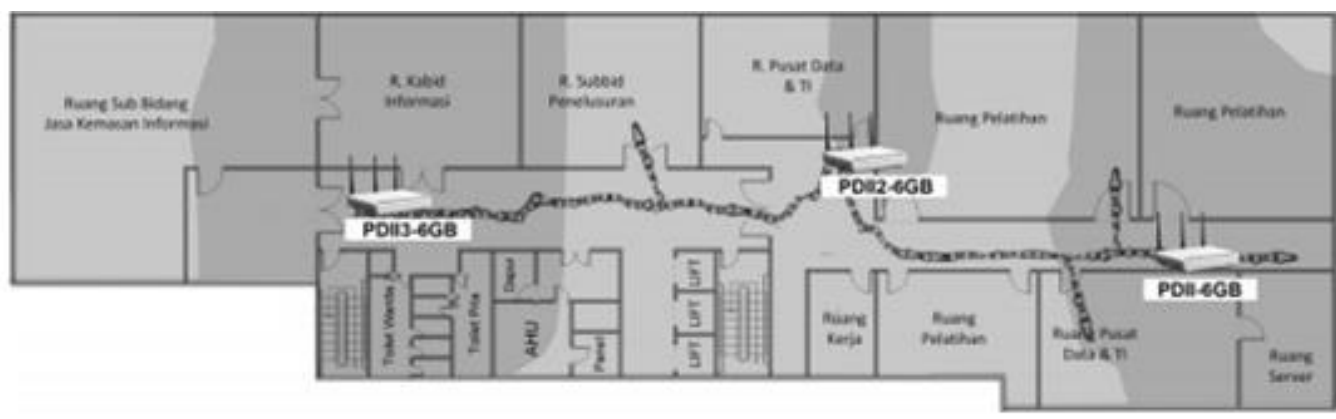

Gambar 28. Jangkauan Sinyal Access Point Usulan di Lantai 6

Dari hasil pengukuran sebaran sinyal Access Point pada jaringan nirkabel usulan jika dibandingkan dengan sebaran sinyal pada jaringan nirkabel eksisting menunjukkan peningkatan, ditunjukkan dengan banyaknya zona warna abu muda di setiap lantai gedung PDII-LIPI yang artinya penyebaran sinyal sudah merata dan sinyal yang diterima kuat. Hal ini menyatakan bahwa dengan letak dan jumlah perangkat access point seperti desain jaringan wireless usulan dapat memberikan sinyal yang menjangkau semua ruangan di setiap lantai PDII-LIPI, sehingga jaringan nirkabel diharapkan dapat mendukung proses bisnis PDII-LIPI terutama dalam hal infrastruktur jaringan.

\section{KESIMPULAN}

Penelitian ini mempresentasikan suatu perbandingan antara topologi jaringan eksisting yang dimiliki oleh PDII-LIPI dan usulan perbaikan topologi jaringan sebagai berikut:

1. Identifikasi topologi jaringan kabel dan nirkabel PDII-LIPI menghasilkan pada saat ini topologi jaringan belum mendukung redudant link sehingga kebutuhan koneksi internet dengan kriteria high availability belum terpenuhi karena jika ada kabel utama putus tidak ada jalur alternatif, kemudian untuk perangkat sudah cukup memadai, dan untuk tata letak masih tidak teratur dan jumlah akses point yang masih minim sehingga menyebabkan jangkauan sinyal kurang merata disetiap ruangan dan

2. Dilakukan perancangan topologi infrastruktur usulan baik kabel maupun nirkabel dengan konsep Cisco Three-Layered Hierarchial Model dimana sudah mendukung redudant link artinya sudah ada jalur backup sehingga kebutuhan koneksi internet dengan kriteria high availability sudah terpenuhi. Selain itu, tata letak akses point sudah di atur dan jumlah akses point nya ditambah sehingga jangkauan sinyal access point sudah merata di setiap lantai di PDII-LIPI. Dan untuk perangkat topologi jaringan yang diusulakan penggunaannya oleh PDII LIPI tidak dirubah karena sudah cukup untuk mendukung proses bisnis yang ada di PDII-LIPI. 
Desain Topologi Jaringan Kabel Nirkabel PDII-LIPI dengan Cisco Three-Layered Hierarchical menggunakan NDLC

\section{DAFTAR PUSTAKA}

Fathinuddin, \& Teguh. (2014). Perancangan Topologi Jaringan Pada Pemerintah Kabupaten Bandung Dengan metodologi NDLC menggunakan GNS3. Seminar Nasional Teknologi Informasi dan Aplikasinya (hal. B-188). Malang: Politeknik Negeri Malang.

Kementerian Komunikasi Dan Informatika Republik Indonesia. (2014). Kemkominfo: Pengguna Internet di Indonesia Capai 82 Juta. Diakses tanggal 14 Desember 2014 dari http://kominfo.go.id/index.php/content/detail/3980/ Kemkominfo\%3A+Pengguna+Internet+di+Indonesia+Capai+82+Juta/0/berita satke r\#.VIbSaDGUdSg

Asosisasi Penyedia Jasa Internet Indonesia. (2014). Asosisasi Penyedia Jasa Internet Indonesiav - Statistik. Diakses tanggal 14 Desember 2014 dari http://www.apjii.or.id/v2/read/page/halamandata/9/statistik.html.

Tanenbaum, W. (2011). Computer Networks. USA : Pearson Education, Inc.

PDII-LIPI. (2011). Website PDII-LIPI. Diakses tanggal 10 September 2014 dari http://www.pdii.lipi.go.id/ .

Sofana, Iwan. (2008). Membangun Jaringan Komputer : Mudah Membuat Jaringan Komputer (Wire\&Wireless) untuk Pengguna Windows dan Linux. Bandung : Informatika.

James E. Goldman, P. T. (2004). Chapter 10 : The Network Development Life Cycle. Dalam Applied Data Communications: A Business-Oriented Approach (hal. 375).

James E, G., \& Philips T, R. (2001). Applied Data Communications, A (Third ed.). John Wiley \& Sons.

CISCO. (2014). Cisco - The Hierarchical Network Design Model. Diambil dari Cisco: http://www.cisco.com/web/learning/netacad/demos/CCNP1v30/ch1/1 1 1/index.html

Pusat Dokumentasi dan Informasi Ilmiah. (2014). PDII-LIPI / Pusat Dokumentasi dan Informasi IImiah - Lembaga IImu Pengetahuan Indonesia - Tentang Kami. Diakses 7 Desember 2014 dari PDII-LIPI | Pusat Dokumentasi dan Informasi Ilmiah - Lembaga Ilmu Pengetahuan Indonesia. 